International Journal of Technology 11(4) 722-731 (2020)

Received November 2018 / Revised January 2019 / Accepted July 2020

International Journal of Technology

http://ijtech.eng.ui.ac.id

\title{
Towards Regenerative Architecture: Material Effectiveness
}

\author{
Salahaddin Yasin Baper ${ }^{*}$, Mahmood Khayat ${ }^{1}$, Lana Hasan ${ }^{1}$ \\ ${ }^{1}$ Architectural Engineering Department, Salahaddin University -Erbil, Zanko Street, Kirkuk Road, Erbil City, \\ Kurdistan Region, Iraq, 44002
}

\begin{abstract}
Environmental problems were initiated with the rise of human civilization, and they increased with the rise in technology's contribution to human lives. Researchers in the field of architecture believe that regenerative approaches are systems based on aligning architectural design with natural resources to provide positive outcomes. Regenerative design holds significant promise for a new theory of sustainable architecture. The aim of this paper is to provide a theoretical framework for the concept of regenerative architecture and testing materials' effectiveness (thermal, availability, waste, and toxicity) and impacts on shifting towards regenerative architecture. Materials' thermal properties were examined by determining energy consumption through Ecotect as a simulation program. However, other factors were measured by a checklist derived from an intense review of the literature. The results revealed that the existing current buildings in Erbil City do not lie in the regenerative zone. Moreover, the study also shows that material selection plays a significant role in reducing energy consumption and toxicity levels that result from moving architectural design towards regenerative design.
\end{abstract}

Keywords: Architectural design concepts; Ecotect; Material effectiveness; Regenerative architecture

\section{Introduction}

Regenerative architecture (which goes beyond the scope of sustainable design) is considered the highest architectural design concept in terms of positive productivity towards the environment, while sustainability aims at being neutral, which mean less harm to nature and the environment. These aims can be achieved by implementing some theories, such as place-based theory, co-evolution system theory, and whole and living system theory. The "regenerative design" term has been newly integrated into the architectural design area, but the major principals that have recently been recognized as regenerative design tenets are mainly based on the previous works of ecological design professionals (Williams, 2014). Therefore, a change in mindset is needed to produce a regenerative design whose goal is not only causing less damage but also making designs contribute to maintain the ecological system as healthy and productive (Reed, 2007; Baper, 2013; Cole, 2015; Berawi, 2017).

This paper has two main objectives. The first objective is to establish a multidimensional model for regenerative architecture, which includes the most effective parameters.

${ }^{*}$ Corresponding author's email: salahaddinbaper@yahoo.com, Tel.: +964-750-4091111; +964 7504534859 doi: 10.14716/ijtech.v11i4.2631 
The second objective is to extend the efficiency analysis of material effectiveness strategies that improve cost effectiveness, energy consumption, and the use non-toxic, ecologically regenerative materials in housing complexes projects in Erbil City. The selection of typical housing projects will urge investors as well as householders to consider the importance of material effectiveness during construction periods. The goal is to design a model that can propose net-positive contributions and add value by using new strategies that shift from net-zero to net-positive, creating zero waste, which has a greater output than its input. In other words, regenerative architecture intends to adapt the current available technologies towards a new system that provides no waste with positive outcomes by melding architecture's physical properties within nature (ground, native plants, and ecological surroundings). It is a representation of an essential rethinking of architectural design by controlling the use of energy, water, carbon emissions, and waste generation reduction (Zari, 2009; Zari and Jenkin ,2010).

In parallel, the study discusses material effectiveness strategies that have been proposed to improve cost effectiveness, energy consumption, and the use of non-toxic, ecologically regenerative materials in housing complex projects in Erbil City. Locally available materials must be used in regenerative projects that contribute to broadening the regional economy in sustainable practices, products, and services (Living Building Challenges, 2012).

The construction of buildings consumes large volumes of resources, which is why material choices between biodegradable, recycled, and sustainable materials makes a huge difference (Franzoni, 2011). Material selection is crucial because it can change a building from sustainable to regenerative. A sustainable building can be constructed using greenmaterial construction. Similarly, utilizing regenerative material-construction produces a regenerative building. The selection of typical housing projects will urge investors as well as householders to consider the importance of material effectiveness during construction periods.

\section{Regenerating system}

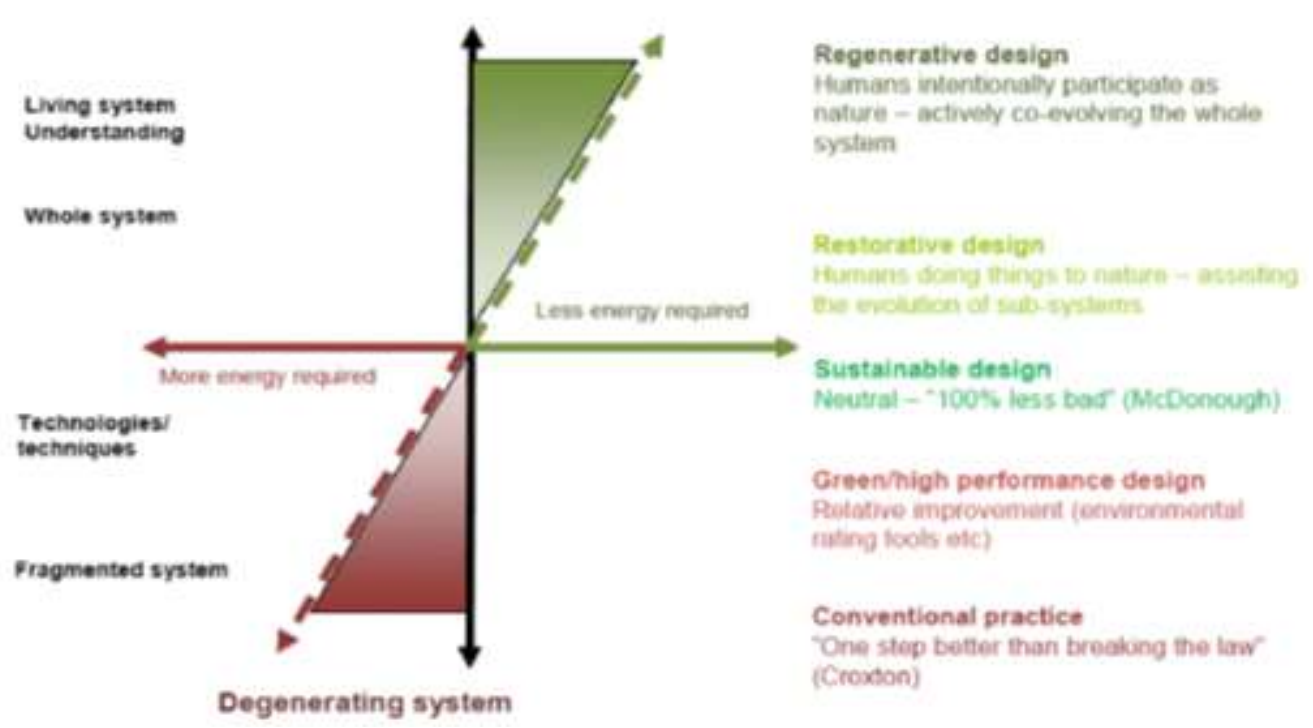

Figure 1 Range of sustainability approaches (Reed, 2007)

\section{Regenerative Architecture Checklist Factors}

To formulate the most effective parameters for regenerative architecture, this study focuses on the relevant literature that relates to sustainability and regeneration, which are 
LEEDS and Living Building Challenges. The theoretical model (Table 1) includes the most effective parameters (dimensions). Each parameter is assigned a range of relevant values within the framework to serve as a model for determining whether the type of buildings are regenerative or not. The most notable parameters of regenerative building are described below.

\subsection{Energy Generation}

Integrated building design has a significant impact on energy use and the environment (Figure 1). The increase of energy consumption in buildings can be resolved by changing buildings' design to use energy efficiently and produce enough energy from the available renewable sources (Kubba, 2010; Berawi, 2016). This section examines this scope and emphasizes important factors that differentiate between net-zero energy and net-positive energy, which is considered regenerative and is relevant to the current study. The relevant definitions are as follows.

\subsubsection{Near-zero-energy building}

The concept of a near-zero-energy building is based on producing energy that is close to its consumption (but not equal) over the course of a year. Theoretically, buildings may be designed to achieve net-zero energy, but practically, they may not achieve a net-zero energy position in operations every year. Factors that change building energy from net-zero to near-net-zero can be classified as abnormal weather that needs extra heating and cooling energy consumption and below-average solar and wind energy that can change net-zeroenergy-operating buildings into near-net-zero-energy buildings (Pless and Torcellini, 2010)

\subsubsection{Net-zero-energy building}

The concept of a net-zero-energy building is based on producing as much energy as a building consumes over the course of a year. Buildings that can provide their energy requirements from low-cost, locally accessible, nonpolluting, and renewable sources are considered net-zero-energy buildings (Cole and Fedoruk, 2015).

\subsubsection{Net-positive-energy building}

A net-positive energy building produces more energy than it consumes. Simply, a netpositive energy building could be defined as a system that produces more energy than it needs and exports the excess to other buildings or systems (Cole and Fedoruk, 2015).

\subsection{Water Purification}

Water purification is an essential category that plays a part in changing the design and operation of buildings from traditional and degenerative to sustainable and regenerative buildings (Joustra and Yeh, 2015). Increasing water system efficiency or generating closedloop (net-zero) water systems depends on the existing water system design and apparatus for buildings that already exist.

\subsection{Material Effectiveness}

Many strategies have been proposed to improve cost effectiveness in the construction industry. However, regenerative architecture intends to use non-toxic, ecologically regenerative, and socially equitable materials (International Living Future Institute, 2014). Material effectiveness is influenced by some factors, which are discussed below in more detail.

a) Local material source

Locally available materials must be used in regenerative projects, which contribute to broadening the regional economy in sustainable practices, products, and services, according to LEED and Living Building standards for regenerative buildings. 
b) Material waste management

Reducing or eliminating waste generated from the all three phases of the building material life cycle-construction, operation, and building demolition (Chileshe et al., 2012) - by recycling and reducing building materials can have environmental benefits, economic benefits, and performance benefits.

c) Non-toxic material choices

The construction of buildings consumes large volumes of resources, which is why material choices between biodegradable, recycled, and sustainable materials makes a huge difference (Franzoni, 2011). Material selection is crucial because it can change a building from sustainable to regenerative. A sustainable building can be constructed by using green material construction. Similarly, utilizing regenerative material construction produces a regenerative building.

\subsection{Thermal Insulation Materials}

Any materials or combination of materials that reduces the rate of heat flow can be considered a thermal insulator. Thermal transmittance, which is usually called "U-value," is the property of materials that indicates the performance of the material in transferring heat flow by convection, radiation, and conduction. It is usually measured in $\mathrm{W} / \mathrm{m}^{2} \mathrm{~K}$.

Moreover, in a steady-state heat transfer, the important parameter is the U-value of the material, which Asdrubali et al. (2015) state to be $0.07 \mathrm{w} / \mathrm{m}^{2} . \mathrm{K}$. However, in non-steady heat transfer, another parameter-the ability of material to store energy-is also considered important. This property is called "specific heat." Accordingly, a good insulator is the one that has a $\mathrm{U}$-value of $0.05 \mathrm{w} / \mathrm{m}^{2} . \mathrm{K}$ and a specific heat of $1.4 \mathrm{~kJ} / \mathrm{kg} . \mathrm{k}$.

Table 1 Regenerative architecture checklist

\begin{tabular}{|c|c|c|}
\hline & Factors & Possible values \\
\hline \multirow{5}{*}{\multicolumn{2}{|c|}{ 1. Energy Generation }} & Non-renewable-energy building \\
\hline & & Near-zero-energy building \\
\hline & & Net-zero-energy building \\
\hline & & Near-positive-energy building \\
\hline & & Net-positive-energy building \\
\hline \multirow{5}{*}{\multicolumn{2}{|c|}{ 2. Water Purification }} & Non-reusable water purification \\
\hline & & Partial water purification \\
\hline & & Neutral water purification \\
\hline & & Near-positive water purification \\
\hline & & Positive water purification \\
\hline \multirow{15}{*}{ 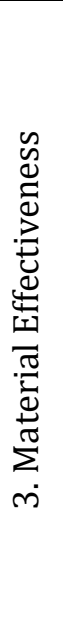 } & \multirow[t]{3}{*}{ Thermal properties } & Material U-values higher than $0.13 \mathrm{~W} / \mathrm{m}^{2} \mathrm{~K}$ \\
\hline & & Material U-values between 0.1 and $0.13 \mathrm{~W} / \mathrm{m}^{2} \mathrm{~K}$ \\
\hline & & Material U-values less than $0.1 \mathrm{~W} / \mathrm{m}^{2} \mathrm{~K}$ \\
\hline & \multirow[t]{5}{*}{ Local material source } & Project material selection does not apply place-based \\
\hline & & Less than $10 \%$ sourced from $800 \mathrm{~km}$ \\
\hline & & $10 \%-20 \%$ material construction budget sourced from 800 \\
\hline & & $20 \%$ material construction budget sourced from $500 \mathrm{~km}$ \\
\hline & & More than $20 \%$ sourced from $500 \mathrm{~km}$ \\
\hline & \multirow[t]{3}{*}{ Waste management } & Open-loop waste managing \\
\hline & & Closed loop with zero waste management \\
\hline & & Closed loop with net-positive waste management \\
\hline & \multirow{4}{*}{ Non-toxic material } & All project materials contain chemicals on the red list \\
\hline & & $75 \%$ of project materials contain chemicals on the red list \\
\hline & & $50 \%$ of project materials contain chemicals on the red list \\
\hline & & $25 \%$ of project materials contain chemicals on the red list \\
\hline
\end{tabular}




\begin{tabular}{|c|c|c|}
\hline & Factors & Possible values \\
\hline \multirow{12}{*}{ 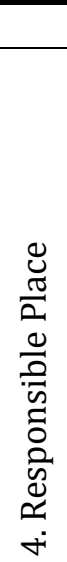 } & & Project free from red-list material \\
\hline & \multirow{5}{*}{ Limits to growth } & Project fully built on previously unused land \\
\hline & & $25 \%$ of the project built on previously used land \\
\hline & & $50 \%$ of the project built on previously used land \\
\hline & & $75 \%$ of the project built on previously used land \\
\hline & & Project fully built on previously used land \\
\hline & \multirow{5}{*}{ Building integrated agriculture } & Project does not achieve urban agriculture requirement zone \\
\hline & & $25 \%$ of project achieves urban agriculture requirement zone \\
\hline & & $50 \%$ of the project achieves urban agriculture requirement \\
\hline & & $75 \%$ of the project achieves urban agriculture requirement \\
\hline & & $100 \%$ of the project achieves urban agriculture requirement \\
\hline & \multirow{5}{*}{ Habitat exchange } & Project does not protect the ecosystem with zero offset area \\
\hline & & Offset area $75 \%$ lower than the developed area \\
\hline & & Offset area $50 \%$ lower than the developed area \\
\hline & & Offset area $25 \%$ lower than the developed area \\
\hline & & Project fully protects the ecosystem with $100 \%$ offset area \\
\hline \multirow{2}{*}{\multicolumn{2}{|c|}{ 5. Indoor Environment }} & Project does not achieve regenerative requirements \\
\hline & & Project achieves regenerative requirements \\
\hline
\end{tabular}

\section{Experiment and Method}

This study attempted to answer the following research questions:

1. What are the most influential factors in assessing regenerative building?

2. What is the impact of different wall material properties on house regenerativity?

For the purpose of the study, the five best housing projects (according to kurdistan investment board classification) in erbil city were selected, which are: Italian city, English village, royal city, dream city, and vital city, as shown in Table 2 . The main reason behind selecting these projects related to the similarity of their building features, quality, buildup area, and envelopes. A comprehensive checklist of factors which derived from the leed performance approach outlined the theoretical framework that contains five major factors (energy generation, water purification, material effectiveness, responsible place and indoor environment).

Table 2 Selected case features

\begin{tabular}{|c|c|c|c|c|}
\hline Cases & Area & Building Features & Building Envelope & Documentation \\
\hline $\begin{array}{l}\text { Case no. } 1 \\
\text { Italian City }\end{array}$ & $320 \mathrm{~m}^{2}$ & $\begin{array}{l}\text { Hipped roof design } \\
\text { with arched } \\
\text { window facade }\end{array}$ & $\begin{array}{l}\text { Cement plastering and } \\
\text { expanded polystyrene }\end{array}$ & \\
\hline $\begin{array}{l}\text { Case no. } 2 \\
\text { English } \\
\text { Village }\end{array}$ & $320 \mathrm{~m}^{2}$ & $\begin{array}{l}\text { Pitched roof } \\
\text { design, simple } \\
\text { facade }\end{array}$ & Limestone cladding & \\
\hline $\begin{array}{l}\text { Case no. } 3 \\
\text { Royal Villa }\end{array}$ & $340 \mathrm{~m}^{2}$ & Flat roof design & $\begin{array}{l}\text { Cement plastering and } \\
\text { limestone cladding }\end{array}$ & 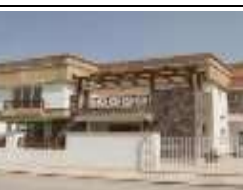 \\
\hline
\end{tabular}




\begin{tabular}{lcllll}
\hline \multicolumn{1}{c}{ Cases } & Area & Building Features & Building Envelope & Documentation \\
\hline $\begin{array}{l}\text { Case no. } 4 \\
\text { Dream City }\end{array}$ & $350 \mathrm{~m}^{2}$ & Flat roof design & Limestone cladding & \\
\hline $\begin{array}{l}\text { Case no. } 5 \\
\text { Vital City }\end{array}$ & $390 \mathrm{~m}^{2}$ & $\begin{array}{l}\text { Sloped roof } \\
\text { (aligned roof) } \\
\text { design) }\end{array}$ & $\begin{array}{l}\text { Cement plaster } \\
\text { cladding and expanded } \\
\text { polystyrene }\end{array}$ & & \\
\hline
\end{tabular}

\section{Results and Discussion}

\subsection{The Applications of the Theoretical Framework}

After applying the checklist factors to local cases, the results indicated that all the local cases are within conventional design approach. Therefore, to fulfil its second objective, the study tested materials' effectiveness (thermal, availability, waste, and toxicity) and impacts on shifting towards regenerative architecture. The materials' thermal properties were examined by determining energy consumption using Ecotect as a simulation program. However, other factors were measured using a checklist derived from an intense review of the literature. For the purpose of calculating the heating and cooling loads, a model of the house with its surroundings was created using Ecotect simulation software, as shown in Figure 2. The surroundings and orientation were also considered to obtain better and more accurate results.

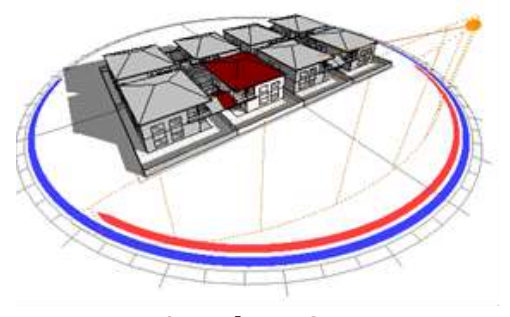

A-Italian City

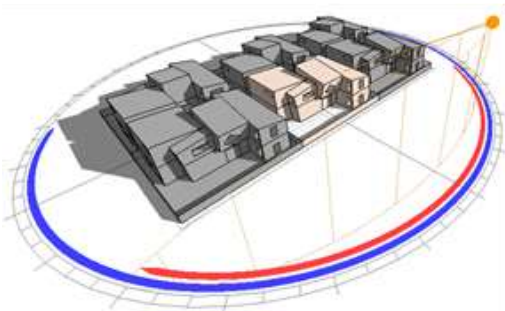

C-Vital City

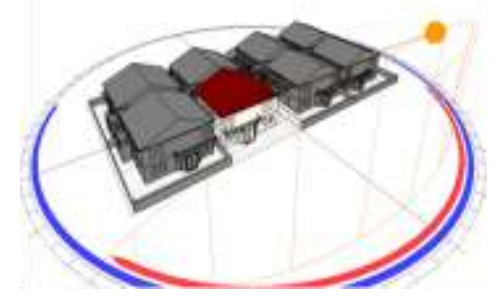

E-English village

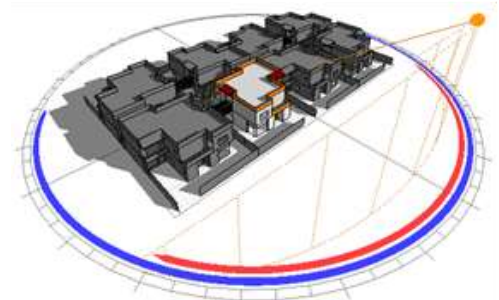

B-Royal Villa

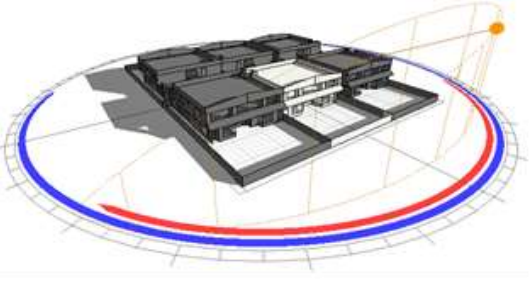

D-Dream City

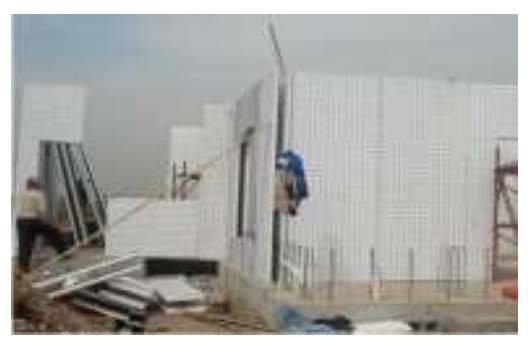

Wall material of Italian city

Figure 2 Ecotect simulation software for different Models in Erbil City 


\subsection{Simulation Results for Different Wall Configurations}

Different wall configurations were taken into consideration as the purpose of clarifying the impacts of different construction materials on energy consumption. Thus, two different insulation materials with different thicknesses and forms were used in the simulation process. All considered scenarios of wall sections with descriptions are illustrated in Figure 3.

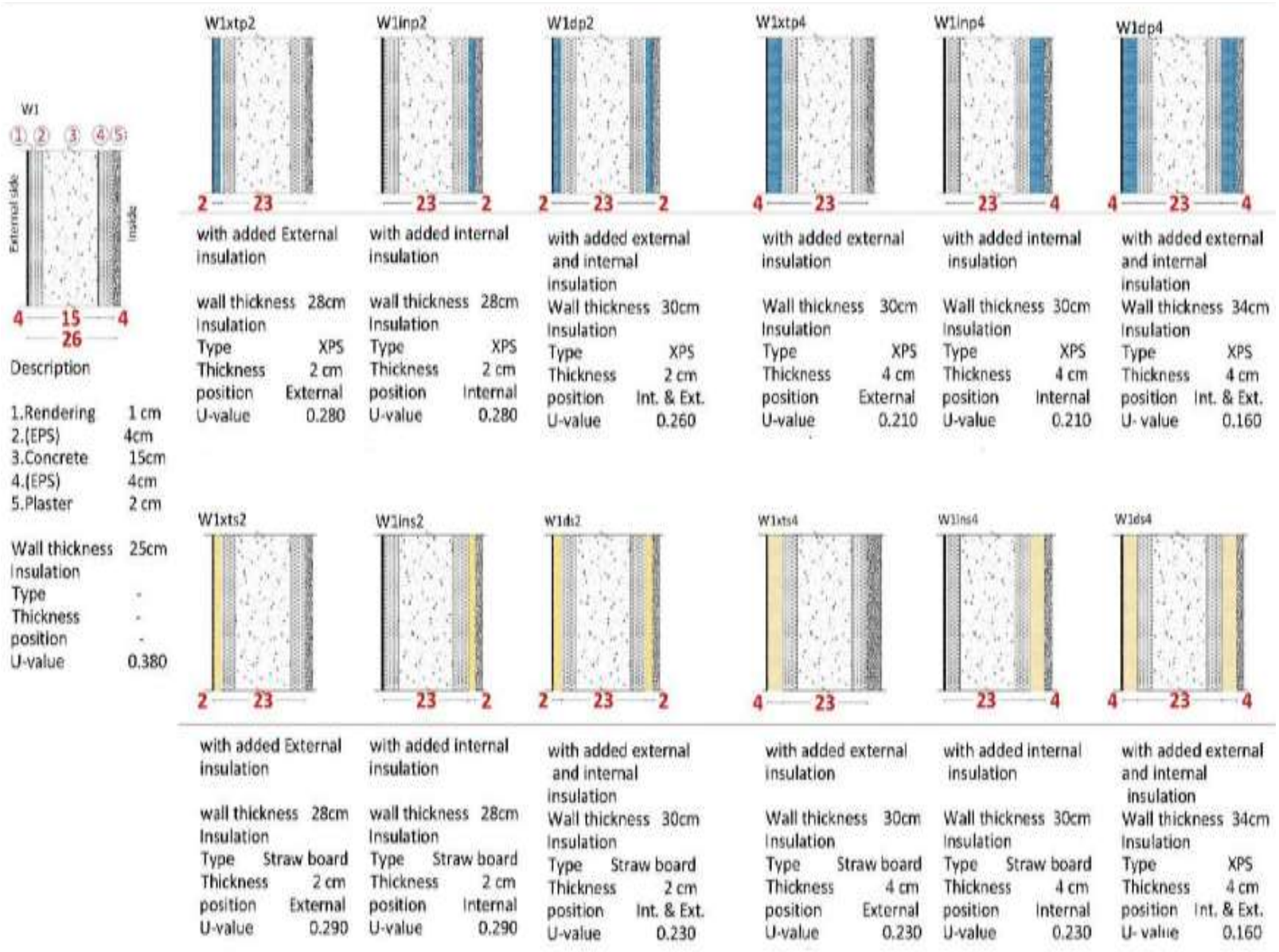

Figure 3 Simulation results of different scenarios for Case no. 1 (Italian City 1)

The above results show the functionality of adding insulation materials to the "as built" wall configuration. However, the best case cannot only be obtained by adding insulation material in a random thicknesses and form. The results showed that the best outcome can be obtained when a double layer of insulation materials is added.

\subsubsection{Comparison between five case studies in terms of wall configurations}

The overall results showed that all the considered cases are not regenerative in terms of construction materials and energy consumption. The performance of the five different house wall configurations was compared earlier to understand the impact of each parameter on annual energy consumption. The "as built" cases were compared to determine the best "as built" wall configuration. The comparison showed that case W4 had a better wall configuration in improving annual energy consumption, achieving the lowest energy consumption.

The comparison between U-values of all the considered cases showed that the W4 case study had the lowest U-value. Hence, there is a proportional relationship between energy consumption and U-value. This finding can be clearly observed in which low U-values resulted in lower heating and cooling loads needed for obtaining thermal comfort. 
However, according to the literature, a sustainable wall must have a U-value of $0.1 \mathrm{~W} / \mathrm{m}^{2} \mathrm{~K}$. Thus, none of the five cases showed U-values below that minimum U-value. Therefore, achieving regenerative wall configurations is not possible using "as built" material alone.

\subsubsection{Comparison between the considered scenarios for all case studies}

Using insulation materials to decrease energy consumption and move towards regenerative design showed that the best results can be achieved when a double layer of 4 $\mathrm{cm}$ insulation materials were used as an additional layer to the "as built" wall materials. However, the effects were different in different case studies. For example, consider the difference between the energy consumed in both the "as built" and best scenarios of the case study. However, in Dream City, the effect of using insulation material resulted in a drop in energy consumption by $31 \%$, which is considered an efficient modification to a wall configuration.

\subsubsection{Comparison between wall configurations according to source, waste management and toxic level}

The results in Table 3 show that using straw board as an additional insulation material is better than extruded polystyrene insulation material in terms of toxicity, local availability, and recyclability. However, it should also be mentioned that using XPS could reduce energy consumption more efficiently than straw board in three of the reviewed case studies, but environmentally, it is not the best choice. Thus, using straw-board insulation material can lead buildings towards regenerative design.

Table 3 Wall configuration assessment according to source, waste management, and toxic level

\begin{tabular}{|c|c|c|c|c|}
\hline Cases & Scenarios & Material Source & Waste Management & Toxic Level \\
\hline \multirow{3}{*}{ Italian City (W1) } & "As built" & $59.79 \%$ & $11.64 \%$ & $0.219 \%$ \\
\hline & $8 \mathrm{~cm}$ XPS & $45.50 \%$ & $10.99 \%$ & $0.816 \%$ \\
\hline & $8 \mathrm{~cm} \mathrm{SB}$ & $62.20 \%$ & $32.73 \%$ & $0.219 \%$ \\
\hline \multirow{3}{*}{ English Village (W2) } & "As built" & $100 \%$ & $0 \%$ & $0 \%$ \\
\hline & $8 \mathrm{~cm} \mathrm{XPS}$ & $77.42 \%$ & $2 \%$ & $0.563 \%$ \\
\hline & $8 \mathrm{~cm} \mathrm{SB}$ & $93.24 \%$ & $22.53 \%$ & $0 \%$ \\
\hline \multirow{3}{*}{ Royal Villa (W3) } & "As built" & $16.6 \%$ & $0 \%$ & $0 \%$ \\
\hline & $8 \mathrm{~cm}$ XPS & $12.5 \%$ & $2.25 \%$ & $0.625 \%$ \\
\hline & $8 \mathrm{~cm} \mathrm{SB}$ & $30 \%$ & $25 \%$ & $0 \%$ \\
\hline \multirow{3}{*}{ Vital City (W4) } & "As built" & $15 \%$ & $57.15 \%$ & $0.07 \%$ \\
\hline & $8 \mathrm{~cm} \mathrm{XPS}$ & $10.71 \%$ & $43.4 \%$ & $0.760 \%$ \\
\hline & $8 \mathrm{~cm} \mathrm{SB}$ & $39.28 \%$ & $68.75 \%$ & $0.05 \%$ \\
\hline \multirow{3}{*}{ Dream City (W5) } & "As built" & $100 \%$ & $0 \%$ & $0 \%$ \\
\hline & $8 \mathrm{~cm} \mathrm{XPS}$ & $75 \%$ & $2.25 \%$ & $0.625 \%$ \\
\hline & $8 \mathrm{~cm} \mathrm{SB}$ & $100 \%$ & $25 \%$ & $0 \%$ \\
\hline
\end{tabular}

It can be seen that both the English Village and Dream City case studies used $100 \%$ local material in constructing their walls. Therefore, they can be considered regenerative houses in terms of material source. However, the other case studies used different material combinations in building their walls, and some were not locally available, such that in a case like Vital City, only $15 \%$ of the material was locally available. Hence, XPS is not helpful in making walls regenerative in terms of material source. In contrast, utilizing straw board raises the local availability of material, which makes it a good insulation material to take walls towards regenerative architecture. 
Similarly, it can be observed that only the Italian City and Vital City case studies used materials that can partly be recycled. Vital City is the best case among all five considered cases in terms of waste management. It can also be noticed that adding insulation material increases this percentage, especially when straw board is used.

Another parameter has an important role in assessing buildings in terms of regeneration, which is the toxicity level of the materials used in the construction process. The results represent the level of toxic of the materials utilized in the walls of all five case studies. Italian City is the worst case among all five studied cases in terms of having toxic construction materials. It can also be noticed that adding XPS as an insulation material increases this level dramatically.

\section{Conclusions}

The regenerative architecture concept goes beyond "less bad" or even "net-zero" design approaches to sustainability and aims at "net positive" design in architecture. It aims to regenerate systems with complete effectiveness that allow the co-evolution of humans' built environment along with nature. The most influential factors in assessing regenerative building are: energy generation, water purification, material effeteness, responsible places, and indoor environmental quality. Hence, regenerative architecture can be identified and designed by considering these factors. In other words, a building can be considered regenerative if all the above factors exist in its design. A checklist can also be generated from these five factors to evaluate whether a building is regenerative or not. After applying the checklist factors to local cases in Erbil City, the results indicated that all local cases are within the conventional design approach.

The analysis of the simulation results indicated that all case studies in Erbil City are outside of regenerative design, rather than all considered as degenerative building, because their U-values are greater than $0.1 \mathrm{~W} / \mathrm{m}^{2} \mathrm{~K}$, which is considered the U-value of regenerative buildings by the reviewed literature. However, the comparative study between the U-values of the case studies has shown that Vital City has the closest U-values, at $0.21 \mathrm{~W} / \mathrm{m}^{2} \mathrm{~K}$, to the suggested U-value for regenerative designs.

Despite reducing energy consumption by adding XPS to the "as built" wall material, the level of toxicity in the case studies was raised, which is not allowed in regenerative design concepts, whereas using bio-based materials (straw board) that are locally available has a level of toxicity at almost zero. It can also be recycled, which has positive impacts on sustaining local resources. Therefore, it is recommended to use straw board instead of XPS-regardless of its lower effect in reducing energy consumption.

It is worth mentioning that by changing only the material, regenerative architecture cannot be achieved, as it has been clarified that regenerative construction means positive output, rather than reducing consumption. Therefore, other factors should be dealt with.

\section{Recommendations}

It is recommended to use insulation materials in wall configuration because they decrease energy consumption for heating and cooling. Moreover, among the insulation materials, straw board is recommended due to its good features-such as non-toxicity, recyclability, and local availability-along with its performance in reducing energy consumption. The research also recommends that, in the process of selecting materials for building construction, it is important not to consider only economic factors and aesthetics but also environmental factors. 


\section{References}

Asdrubali et al., 2015. A review of unconventional sustainable building insulation materials. Sustainable Materials and Technologies. Volume (4), pp. 1-17.

Baper, S., Hasan, A.S, Ismail, S., 2013. Modernization Theory and House Garden Transformation; Erbil City as Case Study. ARO-The Scientific Journal of Koya University, Volume 1, pp. 7-13

Berawi, M., 2016. Accelerating Sustainable Infrastructure Development: Assuring Wellbeing and Ensuring Environmental Sustainability. International Journal of Technology, Volume 7(4), pp. 527-529

Berawi, M., 2017. The Role of Technology in Achieving Sustainable Development Goals. International Journal of Technology, Volume 8(3), pp. 362-365

Chileshe et al., 2012.Designing for Zero Waste: Consumption, Technologies and the Built Environment Chapter: 14. Publisher: Earthscan from Routledge. First ed. London: Earthscan.

Cole, R.J., 2015. Net-zero and Net-positive Design: A Question of Value. Building Research and Information, Volume 43(1), pp. 1-6

Cole, R.J., Fedoruk, L., 2015. Shifting from Net-zero to Net-positive Energy Buildings. Building Research \& Information, Volume 43(1), pp. 111-120

Franzoni E. Materials selection for green buildings: which tools for engineers and archietcts? Procedia Engineering Volume (21), pp.883-890.

Hastings, R., Wall, M., 2007. Sustainable Solar Housing: Strategies and Solutions. First ed. London: Earthscan

International Living Future Institute, 2014. Living Building Challenge 3.0. In Place Petal Handbook. Canada, pp. 21-35

Joustra, C.M., Yeh, D.H., 2015. Framework for Net-zero and Net-positive Building Water Cycle Management. Building Research \& Information, Volume 43(1), pp. 121-132

Kubba, S., 2010. LEED Practices, Certificate, and Accreditation Handbook. Burlington: Elsevier

LEED Reference Guide for Building Design and Construction, V4, L., 2014. Available Online at www.greenbuildingacademy.org, Accessed on June 10, 2018

Pless, S., Torcellini, S., 2010. Net-zero Energy Buildings: A Classification System based on Renewable Energy Supply Options. National Renewable Energy Laboratory. U.S. Department of Energy

Reed, B., 2007. Shifting from "Sustainability" to Regeneration. Building Research \& Information, Volume 35(6), pp. 674-680

Reed, B., 2015. The Nature of Positive. Building Research \& Information, Volume 43(1), pp. 7-10

Williams, A., 2014. Regenerative Sustainability Paradigm for the 2014-2024 Decade of Energy for All and the Sustainable Development Agenda 2030. Cleaner Production (SV). Available Online at http://www.elsevier.com/wps/find/journaldiscription .cws_home $/ 30440 /$, Accessed on August 12, 2018

Zari, M.P., 2009. Rethinking Our Built Environments: Towards a Sustainable Future. Wellington, New Zealand: Ministry of Environment

Zari, M.P., Jenkin, S., 2010. Re-defining Cutting Edge Sustainable Design: From EcoEfficiency to Regenerative Development. Sustainable Building Conference (SB10), Edited by: Easton, L., \& Sharman, W., Wellington, SB10 